\title{
OIL MARKET: LOW PRICES RETAINED ${ }^{1}$ Y. Bobylev
}

Low world crude oil prices have resulted in scaling back oil production on high-cost oil deposits and in contraction of investment in the development of unconventional deposits. At the same time, reduction of crude oil extraction from the cost-intensive deposits, first of all, in the US, is offset by the built up production by leading OPEC countries who strive to increase their market share. In 2016, Iran and Saudi Arabia have significantly raised their crude oil output. Russia has also built up production, which hit all-time high since 1990. In 2017, one should expect relatively low oil prices to remain. At the same time, some growth is feasible in comparison with the current year.

The current oil glut market has led to a significant drop of the world prices on oil. The fast growth in tight oil production in the United States was the main factor for supply increase. In this context, OPEC refused to reduce set quotas of crude oil production and actually conducted policy of retaining its market share. As a result, in 2015, average price of Russian Urals moved down to $\$ 51.2$ per barrel, and in January-October 2016 averaged $\$ 40.6$ per barrel (Table 1). In January, it fell to $\$ 28.8$ per barrel, and in October constituted $\$ 47.7$ per barrel (Fig. 1).

Table 1

WORLD OIL PRICES IN 2014-2016, USD/BBL.

\begin{tabular}{|l|c|c|c|c|c|c|}
\hline & 2014 & 2015 & $\begin{array}{c}2015 \\
\text { Q4 }\end{array}$ & $\begin{array}{c}2016 \\
\text { Q1 }\end{array}$ & $\begin{array}{c}2016 \\
\text { Q2 }\end{array}$ & $\begin{array}{c}2016 \\
\text { Q3 }\end{array}$ \\
\hline $\begin{array}{l}\text { Price of Brent, } \\
\text { Great Britain }\end{array}$ & 98.9 & 52.4 & 43.4 & 34.4 & 45.9 & 45.8 \\
\hline $\begin{array}{l}\text { Price of Urals, } \\
\text { Russia }\end{array}$ & 97.7 & 51.2 & 41.5 & 32.0 & 43.6 & 43.9 \\
\hline
\end{tabular}

Sources: IMF, OECD/IEA.

Owing to low prices posted in 2016, downward oil output trend in the cost-demanding oil-fields was retained, first of all regarding tight oil reserves in the US. The US production of oil peaked to $9.6 \mathrm{mn} /$ bbl per day in April 2015, following which it decreased to $9.2 \mathrm{mn} / \mathrm{bbl}$ per day in December 2015, and 8.5 $\mathrm{mn} / \mathrm{bbl}$ per day in September 2016. It fell by $11 \%$ in comparison with April of last year (Fig. 2). Oil output is falling also in China, Mexico, and Australia.

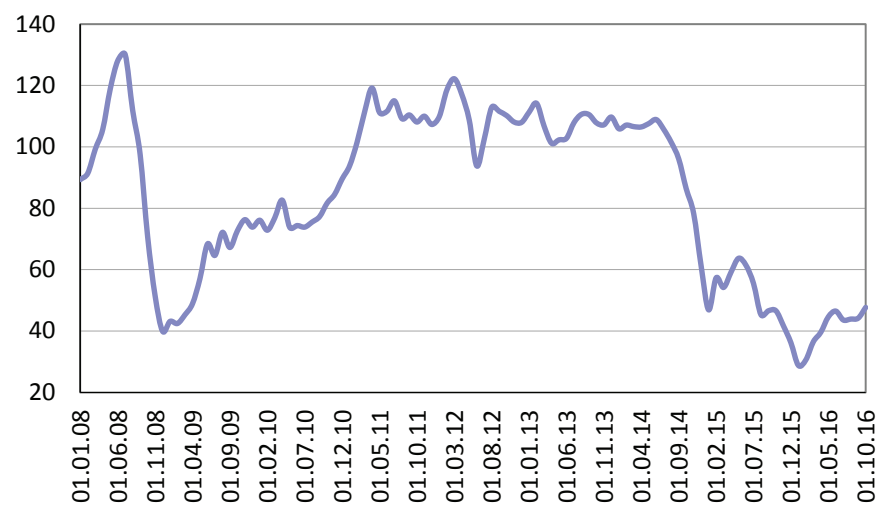

Source: OECD/IEA.

Fig. 1. Price of Urals in 2008-2016, USD/bbl

1 This paper was originally published in Monitoring of Russia's Economic Outlook No.18(36). 
In the wake of low oil prices, investment in the development of the most cost-intensive oil-fields, tight oil in US, bituminous sands in Canada, and deep-water deposits in various parts of the world has shrunk significantly. For example, the number of active oilrigs reached the maximum of 1,596 in October 2014, after which reduction of their number followed (Fig. 3). In December 2015 , the number of rig count came to 537 and in September 2016 416. In other words, the number fell by $74 \%$ in comparison with the pre-crisis period. Downward trend in the investment activity will result in the new future in further fall of the oil output in the United States. Further dynamics of the oil production in the country will depend on the global crude oil prices, as well as on the policy conducted by the new US administration regarding introducing preferential tax treatment of oil companies and allocation of new license blocks.

Contraction of cost-intensive production could have reduced oversupply of crude oil and create

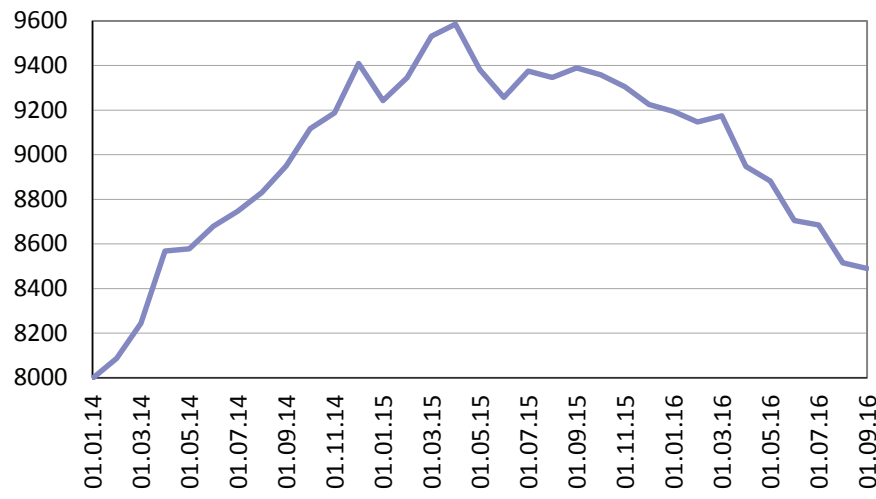

Source: USEIA.

Fig. 2. Oil production in USA in 2014-2016, thousands of barrels per day

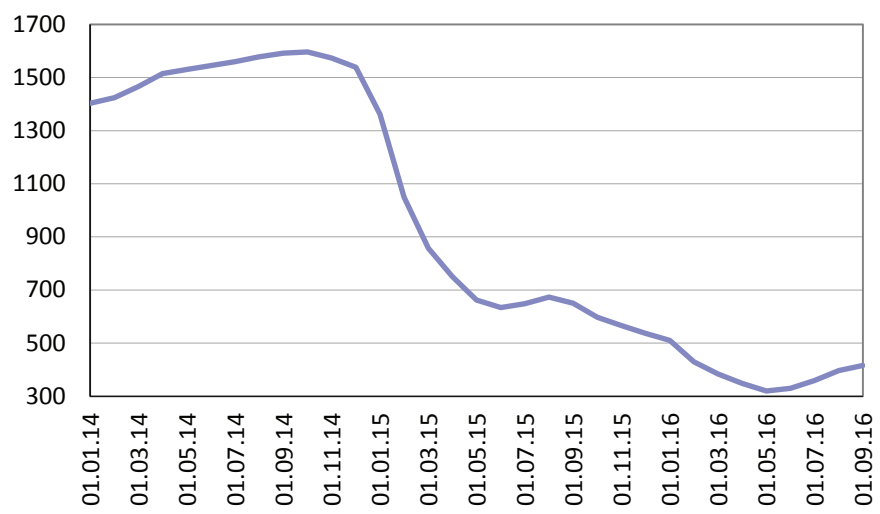

Source: Baker Hughes.

Fig. 3. Number of active rigs in the US in 2014-2016 preconditions for surge of global oil prices. Policy conducted by OPEC presents a serious problem. Those countries strive to extend their market share. Those governments whose revenues decisively depend on the oil export with depressed oil prices enhance incentives to expand the market share. By raising supplies, they want at least partly to offset contraction of revenues owing to the oil price plunge. As a result, contraction of output in high-cost regions currently is offset by production growth in OPEC.

Saudi Arabia, the largest OPEC oil producer, has significantly raised oil output: by $0.96 \mathrm{mn} / \mathrm{bbl}$ per day over last two years (by $0.37 \mathrm{mn} / \mathrm{bbl}$ per day in 2015 and $0.59 \mathrm{mn} / \mathrm{bbl}$ per day in 2016). Iraq, the second largest oil producer in OPEC, has made a major contribution in oil oversupply in 2015 by increasing the output by $0.82 \mathrm{mn} / \mathrm{bbl}$ per day. In 2016, Iran, the third largest oil producer in OPEC, was a major "destabilizer" on the oil market. Thanks to lifted sanctions, Iran increased oil output from $2.8 \mathrm{mn} / \mathrm{bbl}$ per day in Q4 2015 to 3.65 mn/bbl per day in Q3 2016 (Table 2). Thus, output growth in Iran completely offset output contraction in the US in 2016. In the end, there was a constant excess of the previously set production quota on oil production by OPEC ( $30 \mathrm{mn} / \mathrm{bbl}$ per day).

Russia also boasts of upward trend in oil production (Table 3). According to preliminary estimates, Russia's crude oil output will hit $544 \mathrm{~m} \mathrm{t}$, which is the 
Table 2

OIL OUTPUT IN US AND OPEC IN 2014-2016, MN BARRELS PER DAY

\begin{tabular}{|c|c|c|c|c|c|c|c|c|}
\hline & $\begin{array}{c}2014 \\
\text { Q4 }\end{array}$ & $\begin{array}{c}2015 \\
\text { Q1 }\end{array}$ & $\begin{array}{c}2015 \\
\text { Q2 }\end{array}$ & $\begin{array}{c}2015 \\
\text { Q3 }\end{array}$ & $\begin{array}{c}2015 \\
\text { Q4 }\end{array}$ & $\begin{array}{c}2016 \\
\text { Q1 }\end{array}$ & $\begin{array}{c}2016 \\
\text { Q2 }\end{array}$ & $\begin{array}{c}2016 \\
\text { Q3 }\end{array}$ \\
\hline USA & 9.25 & 9.49 & 9.47 & 9.41 & 9.30 & 9.17 & 8.85 & 8.68 \\
\hline $\begin{array}{l}\text { OPEC, } \\
\text { total }\end{array}$ & 30.34 & 31.06 & 31.74 & 32.19 & 31.99 & 31.77 & 32.41 & 32.84 \\
\hline $\begin{array}{l}\text { Saudi } \\
\text { Arabia }\end{array}$ & 9.63 & 9.73 & 10.07 & 10.22 & 10.00 & 9.98 & 10.33 & 10.59 \\
\hline Iraq & 3.53 & 3.49 & 3.97 & 4.30 & 4.35 & 4.29 & 4.38 & 4.42 \\
\hline Iran & 2.80 & 2.80 & 2.80 & 2.80 & 2.80 & 3.03 & 3.57 & 3.65 \\
\hline
\end{tabular}

highest level since 1990. Recent years' investments and the ruble's devaluation have significantly contributed to the crude oil production.

A number of factors, which contribute to retention of relatively low oil prices, characterizes current global oil market. The paramount among them are significant volumes of tight reserves in the US, which will be rapidly drawn into development and will increase supply with oil prices above $\$ 60$ per barrel; slowdown of economic growth in China; highly low level of discipline in OPEC, as well as feasibility of increasing production in certain countries, which are beyond OPEC. In this context, retention of relatively low prices of oil in the years to come is the most likely prospect for the oil market.

At the same time, in 2017, owing to a fall of tight oil production and reduction of oversupply of oil, some increment of global oil prices is feasible in comparison with the current year. Latest forecasts made by leading international organizations regarding global oil prices for 2017 stay in the range of \$45-55 per barrel. According to the IMF forecast basket price for oil in 2017 will come to $\$ 50.6$ per barrel, the World Bank forecast $-\$ 55.2$ per barrel, the US Energy Information Administration - \$50.9 per barrel, OPEC - \$45 per barrel. Some growth of world oil prices is expected in the future. For example, according to the IMF forecast, in 2018 the oil price will hit $\$ 53.1$ per barrel (Table 3).

Table 3

FORECASTS OF GLOBAL OIL PRICES, USD/BBL

\begin{tabular}{|l|c|c|}
\multicolumn{1}{|c|}{ Organization } & 2017 & 2018 \\
\hline International Monetary Fund: basket price of oil* & 50.6 & 53.1 \\
\hline World bank: basket price of oil * & 55.2 & 59.9 \\
\hline OPEC basket price & 45.0 & 50.0 \\
\hline US Energy Information Administration: Brent price & 50.9 & \\
\hline
\end{tabular}

* Average price of Brent, Dubai and WTI.

Sources: IMF, WB, OPEC, USEIA. 